\title{
The Influence of Cultural Factors, Social Factors, and Personal Factors against Customer Purchase Decisions in Using Wedding Services Organizer in Surabaya
}

\author{
Rachmat Santosa \\ Ciputra Group \\ rachmatsantosa22@gmail.com \\ https://doi.org/10.37715/rmbe.v1i2.2415
}

\begin{abstract}
Wedding organizer services are needed and sought to help resolve problems owned by the prospective bride and groom. This study aims to examine and analyze cultural factors, social factors and personal factors as variables that influence customer purchasing decisions in using wedding organizer services in Surabaya. This type of research is quantitative, the sampling technique used is purposive sampling in the form of a number questionnaire where the population is unknown. By using the criteria of respondents who are married and the age of marriage that runs a maximum of 5 (five) years and uses the services of a wedding organizer. A sample of 97 respondents was obtained from the calculation of the formula unknown population. The results obtained that cultural factors have a positive and significant influence on purchasing decisions. But social factors and personal factors partially do not significantly influence the purchase decision. So business managers must improve their outlook on finding clients and improving the quality of services so that customers are easier to choose these services.
\end{abstract}

Keywords - Cultural Factors, Social Factors, Personal Factors, Purchasing Decisions, Wedding Organizer.

\section{Introduction}

Wedding day arrangements involve many processes and details (Napompech, 2014). This makes wedding organizer services much needed and sought to solve the problems that prospective bridal couples have.

Table 1.1. Projection of Population Data in Surabaya in 2019

\begin{tabular}{|l|l|l|l|}
\hline \multirow{2}{*}{ Umur } & \multicolumn{3}{|l|}{ Surabaya City Population Projection (Soul) } \\
\cline { 2 - 4 } & Man & Woman & Amount \\
\hline $\mathbf{0}-\mathbf{3 4}$ & 830.016 & 828.468 & 1.658 .484 \\
\hline $\mathbf{3 5}-\mathbf{7 5 +}$ & 600.972 & 636.739 & 1.237 .711 \\
\hline
\end{tabular}

Source: Central Bureau of Statistics, with Own Process.

From the data in Table 1.1. obtained from the summary of the Surabaya population projection in 2019 by the Central Statistics Agency, it can be concluded that the number of young people aged 0-34 accounts for more than half of the total population in Surabaya. According to the Surabaya City Population and Civil Registration Service, which can be accessed through the website www.dispendukcapil.surabaya.go.id, 8,416 couples have registered at the service as of April 23, 2019. This means that there are still 821,600 men and 820,052 unmarried women. And this is proof that this wedding organizer service business is a business that has a great opportunity to continue to grow and be needed in the future.

Rachmat Santosa, SA (CEO) as the author and Firstarizki Huda Sultan, S. Pd (Founder) is the originator of the idea to establish Bolodewe Wedding and Event Organizer in August 2017. With the experience of its founders in the field of services Event Organizer, then this business is the most suitable and can provide benefits for both. Consumers need information to determine what they will buy, at what price and how the quality of the product or service itself is because it is the right of the consumer. As what has been written by Kotler and Keller (2016) in their book, there are several factors that determine consumers in buying a product or service, some of which are cultural, social, cultural, and psychological factors. One of the most influential on a person's buying interest is social factors (Kotler \& Keller, 2016a). How is the condition of the family and how the surrounding group affects and what status he gets after buying a product and or service. 
Table 1.2. Client Data Bolodewe Wedding Organizer 2018 - 2019

\begin{tabular}{|c|c|c|}
\hline Client Fee & Number of Events Yr. 2018 & Number of Events Yr. 2019 \\
\hline IDR 100 million < & 2 & 1 \\
\hline >Rp 100 Million & 3 & 6 \\
\hline Total & 5 & 7 \\
\hline
\end{tabular}

Source: Observation Results / Personal Data.

From the data in Table 1.2., it can be seen that the data on clients who used wedding organizer $\mathrm{X}$ during 2018 were 5 events and in 2019 there were 7 events. A total of 9 events from 2018 to 2019 the funds needed by clients to carry out their wedding events were more than IDR 100,000,000 (one hundred million rupiah) and only 3 events used funds of less than IDR 100,000,000 (one hundred million rupiah). The more it costs in an event, the more luxurious and complete the decorations and clothing used, good food and a place for the event are that are quite expensive, indicating that this is how their status in a group is and how the nature and behavior of the families of the stakeholders are.

To find out how the customer's decision in considering the selection of wedding organizer services, the researcher conducted a pre-survey which was carried out at the Citraland Surabaya marketing office. In short question interviews and with a question method that is expressed explicitly to people who are married and use the services of a wedding organizer, at the time before marriage, what factors are considered in choosing a wedding organizer ?". 10 people were sampled in this survey, and it was found that $60 \%$ (40\% friend references and $20 \%$ family decisions) from 10 respondents showed a relationship with social factors. Rambi (2015) himself in his journal revealed that family and friends influence customer purchasing decisions. As many as $30 \%$ of 10 people answered that the available costs refer to one of the factors in consumer behavior, namely personal factors which according to Nawawi (2016) purchasing decisions are closely and sensitively related to income and economic conditions. Lastly, $10 \%$ of the respondents chose to use the services of a wedding organizer because usually when weddings with Arab culture take place, they use certain services which always carry out events using Middle Eastern customs so they no longer need to be explained in too much detail.

\section{Literature Review}

\subsection{Previous Research}

The study was written by Pemani et al. (2017) entitled "The Influence of Personal Factors on Consumer Purchase Decisions". The survey, which was conducted on Everbest shoe products, was aimed at consumers in Manado. Some of these personal factors are age and stage of life cycle, occupation and economic conditions, lifestyle and personality. A total of 100 respondents as a sample was collected and the results showed that these factors had a significant effect on purchasing decisions for Everbest brand shoes in Manado. So Pemani et al. (2017) provide advice to the company to continue to maintain its strategy. The connection with this research is the calculation of the economic conditions and the subject's occupation.

Finally, the same research was also carried out by Suawa et al. (2019) with the title "Analysis of Factors Influencing Consumer Behavior on Purchase Decisions at New Ayam Bandung Resto Megamas Manado Area". This study involved 30 respondents using purposive sampling technique and data analysis technique using multiple linear regression analysis. There are 4 independent variables, namely cultural factors, social factors, personal factors and psychological factors and the dependent variable is purchasing decisions. The results obtained in this study, the independent variables simultaneously or jointly have a significant effect on the dependent variable. Meanwhile, each of them is known in their research that cultural factors do not significantly influence purchasing decisions, as well as social factors and personal factors which also do not significantly influence purchasing decisions. Only psychological factors have a significant effect on purchasing decisions for New Ayam Bandung Resto. Conclusions and suggestions that can be drawn in this study are business managers must pay attention and understand about actual consumer behavior and improve strategies in managing businesses in order to achieve competitive advantage. The relationship with this research is the use of 3 factors of consumer behavior as the independent variable and purchasing decisions as the dependent variable. 


\subsection{Theoretical basis}

\subsubsection{Consumer Behavior}

According to Sopiah and Sangadji (Sopiah \& Sangadji, 2013, p. 7), consumer behavior is an action that is directly involved in obtaining, consuming, and disposing of products or services, including the processes that precede and follow these actions. Consumer behavior is basically a natural trait caused by humans and is a stimulus for humans to make decisions when buying goods and or services. The theory expressed by Schiffman and Kanuk (2010, as cited in Nofri \& Hafifah, 2018), states that consumer behavior describes the way individuals make decisions to utilize their available resources (time, money, effort) to buy consumption-related goods. Meanwhile, according to Engel, et al in Nofri and Hafifah (2018) consumer behavior is an action that is directly involved in obtaining, consuming, and disposing of products and services, including the processes that precede and follow from these actions.

\subsubsection{Factors Influencing Consumer Behavior}

It is stated that there are four kinds of factors that influence consumers in making their decisions, which are conveyed by Kotler and Keller (2016b) in their book entitled Marketing Management as follows:

1. Cultural Factors: Culture is the most basic determinant of desire and behavior to obtain values, perceptions, preferences and behaviors from other important institutions. There are several indicators of cultural factors according to Kotler and Keller (2016b), some of which are (people's habits: the same behavior that lasts a long time in a society, area of residence (geographical area that provides more specific identification and socialization), racial groups ( different ethnic niches do not always respond positively to mass market advertising)

2. Social Factors: Social class is a relatively homogeneous and permanent division of society that is hierarchically structured and whose members share similar values, interests, and behaviors. Social class is determined by a single factor, such as income, but is measured as a combination of occupation, income, education, wealth, and other variables. There are several indicators of social factors according to Kotler and Keller (2016b), some of which are reference groups (all groups that have a direct and indirect influence on the attitude or behavior of the person), family (family members represent the most influential main reference group), the role and status of parents (a role that bears status as a potential symbol).

3. Personal Factors: Personal factors are defined as psychological characteristics of a person that are different from others that cause relatively consistent and enduring responses to the environment. Buying decisions are also influenced by personal characteristics, namely age and life cycle stage, occupation, economic situation, lifestyle, personality, and self-concept. There are several indicators in the personal factor according to Kotler and Keller (2016b), some of which are jobs, economic capacity, lifestyle, personal character.

4. Psychological factors: Psychological factors as part of the influence of the environment in which he lives and lives at the present time without ignoring the influence of the past or his anticipation in the future. The choice of goods purchased by a person is further influenced by important psychological factors (motivation, perception, knowledge, beliefs, and attitudes)

\subsubsection{Buying decision}

Decision is the selection of two or more alternative choices (Schiffman \& Kanuk, 2010). If someone has the choice to buy or not an item between $\mathrm{A}$ or $\mathrm{B}$ or $\mathrm{C}$, etc., then that person is in a position to make a purchase decision. However, if people have no other choice and are forced to buy an item or service, then it is not included in making a purchase decision (Schiffman \& Kanuk, 2010). This state of compulsion can be referred to as "Hobson's choice". There are several indicators of cultural factors according to Sumarwan (2015) some of which are the need for services, information seeking, evaluation, recommending to other parties. Types of buying decisions:

1. Complex-Buying Behavior : This stage is a type of consumer that is very detailed and significant in purchasing a product from several brands (Kotler \& Amstrong, 2016).

2. Dissonance-Reducing Buying Behavior : In this type of second-level buying decision, it explains that the consumer's buying decision is determined by a situation that requires the participation of the seller 
to explain a product/service thoroughly, but only a few kinds of brands are described (Kotler \& Amstrong, 2016).

3. Habitual Buying Behavior : According to Kotler and Amstrong (2016) this behavior is carried out by lower-level consumers and only knows a few brands. This happens because there is no consumer awareness to learn about a desired product/service at all. With this type of consumer, they will tend to choose the cheapest price and can be purchased repeatedly (Kotler \& Amstrong, 2016).

4. Variety-Seeking Buying Behavior : As the name implies, this type is a consumer who prioritizes product variety rather than the strength of the product itself (Kotler \& Keller, 2012). For minor brands, they only need to vary promos, coupons, provide free samples and advertisements that better show why consumers need to try new flavor variants (Kotler \& Amstrong, 2016).

In choosing a product or service, consumers will sort out all the things that will be taken into consideration such as product, price, place, and promotion. There are several other things that are also considered by consumers, namely economic, technological, social, and cultural factors (Kotler \& Amstrong, 2016). From these things, it will also become a buyer's black box, namely a situation where consumers take careful consideration of the considerations received before making a decision. In making a decision, there are several other views expressed. The four most important things in the perspective of decision making are divided into four kinds (Schiffman \& Kanuk, 2010) namely the economic view, the passive view, the cognitive view, and the emotional view.

This economic view itself refers to a decision that is made rationally or consciously about: all available product alternatives, able to rank each alternative appropriately from the point of view of its advantages and disadvantages, able to identify the best alternative (Schiffman \& Kanuk, 2010). However, to master these three things is very rare for consumers. Thus, the decisions taken may not be as perfect as possible. This has been proven by classical economic methods that humans with a high level of rationality will never exist. The reason is that humans are limited by their existing skills, habits, and reflexes, humans are limited by their existing values and goals, and humans are limited by the breadth of knowledge Herbert A.

This passive view is categorized as consumers who accept what the product or service is offered, and there is no willingness to find and compare similar products or services as their reference in buying a product or service. In other words, consumers are perceived as impulsive and irrational buyers, ready to surrender to the goals and power of marketers (Schiffman \& Kanuk, 2010).

The Cognitive View explains that this type of consumer is very active in finding out about the goods to be purchased, from finding out the details of the product/service information, seeing the distribution channels, and prices. However, consumers will stop making comparisons until they are "satisfied" with the information that has been obtained, not because they have received the most complete information. When viewed from his position, a person with a cognitive view is between a passive view and an economic view (Schiffman \& Kanuk, 2010).

This Emotional View is associated with situations where a person decides to buy because it is based on past situations or feelings to remember in the present. This can be seen as someone buying roses because he remembered his lover gave extraordinary appreciation at dinner by sprinkling roses on the left and right all the way to the dining table. These emotional things make a person less willing to do comparisons or look for cheaper similar items. The most important thing is that the buyer can restore the memory that occurred at that time for the goods he bought (Schiffman \& Kanuk, 2010).

\section{Research Methods}

\subsection{Data collection methods and techniques}

This research is a kind of quantitative research with an explanatory survey research method. According to Sugiyono (2014), the expansion survey research method is a research method carried out in large and small populations, but the data studied are data from samples taken from the population, so that relative events, distributions, and relationships between variables are found. .

In this study, the variable $\mathrm{x}$ that is determined is consumer behavior which contains cultural factors, social factors, and personal factors. While the specified variable y is consumer purchasing decisions. The population is a generalization area consisting of subjects who have certain qualities and characteristics determined by the researcher, then conclusions are drawn (Sugiyono, 2014). The population to be studied is newly married couples in Surabaya. The total population in this study is unknown. The sample is part of the number and certain characteristics possessed by the population (Sugiyono, 2014). The sampling technique used in this study used purposive sampling, namely the method or technique of determining the sample by determining certain criteria (Sugiyono, 2014). This 
criterion is determined by respondents who are married and use the services of a wedding organizer, as well as the age of marriage that has been running for a maximum of 5 years.

The data collection method with the type of research data relates to the data sources used by researchers to obtain quantitative research data, namely obtaining data using numerical questionnaires or qualitative data in the form of numbered questionnaires (Sugiyono, 2014).

This study uses primary data, namely data obtained from respondents through questionnaires. While secondary data was obtained from data from the Bolodewe Internal Wedding and Event Organizer in 2018 - 2019. In its application, the questionnaire will use a Likert scale measurement method. This scale is used to measure attitudes, opinions and perceptions of a person or group of people about social phenomena (Sugiyono, 2014). The scale given in this study was "Strongly Agree, Agree, Disagree, Disagree, Strongly Disagree". For quantitative analysis, each scale will be given a score.

The independent variable in this study is the influence of consumer behavior which is divided into three things: cultural factors, social factors, and personal factors. For the dependent variable in this study is the purchase decision by consumers. The ordinal scale is used in this study. This scale provides information about the relative number of different characteristics possessed by certain objects or individuals (Sarwono, 2006). This level of measurement has nominal scale information plus a certain relative rating tool that provides information whether an object has more or less characteristics but not in the form of many shortcomings and advantages.

\subsection{Data analysis}

\subsubsection{Data Quality Test}

\section{a) Validity test}

According to Sugiyono (2014), the notion of validity is the degree of accuracy between data that actually occurs on the object of research and data that can be reported by researchers. In this study using Pearson correlation. Pearson's fault tolerance level is 0.05 . If the resulting significance value for each variable statement is less than 0.05 , then the statement is considered valid. If the resulting significance value is more than 0.05 , then the statement is considered invalid.

\section{b) Reliability Test}

According to Sugiyono (2014), reliability is related to the degree of consistency and stability of data or findings. In this study, researchers will use the Alpha Cronbach technique. This technique is used to measure the reliability or consistency of the answers given by respondents or a set of questions. The technique correlates each score from the statement in the form of a scale that is done by the respondent on each observation. If the Cronbach's Alpha value generated in this reliability test is above 0.60 , it is considered reliable. On the other hand, if Cronbach's Alpha value is less than 0.60, it is considered unreliable.

\section{c) Multiple Regression Analysis}

Multiple regression analysis is used if the researcher wants to see how the rise and fall of the independent variable is, if two or more independent variables as predictor factors are manipulated (increase in value). So that multiple regression analysis is carried out if the independent variable is at least 2 (Sugiyono, 2014). In this study there are 3 variables used, therefore the form of the regression equation is :

$$
\mathrm{Y}=\beta_{0}+\beta_{1} \mathrm{X}_{1+} \beta_{2} \mathrm{X}_{2}+\beta_{3} \mathrm{X}_{3+} \varepsilon
$$

Description

Y

$\beta_{0}$

$\beta_{1}, \beta_{2}, \beta_{3}$

$\mathrm{X}_{1}$

$\mathrm{X}_{2}$

$\mathrm{X}_{3}$

$\varepsilon$
$=$ Purchase Decision

$=$ Constant

$=$ Regression coefficient of variable $X_{1}, X_{2}, X_{3}$ studied

$=$ Cultural Factor

$=$ Social Factor

= Personal Factor

$=$ residual 
d) Hypothesis testing

1) $F$ test

If the sig value in the $\mathrm{F}$ test $<0.05$, it can be concluded that the independent variables simultaneously have a significant effect on the dependent variable. Meanwhile, if the sig value in the $\mathrm{F}$ test $>0.05$, it can be concluded that the independent variables simultaneously have no significant effect on the dependent variable.

2) t test

If the sig value resulting from $t$ arithmetic $<0.05$, then Ho can be concluded that the independent variable has a significant partial effect on the dependent variable. Meanwhile, if the sig value resulting from $t$ count $>0.05$, it can be concluded that the independent variable has no partial significant effect on the dependent variable.

3) Test Correlation Coefficient $(R)$ and the coefficient of determination $\left(R^{2}\right)$

The correlation coefficient test is used to measure how big the linear relationship of the independent variables studied is to the dependent variable (Kuncoro, 2013). The correlation coefficient ( $\mathrm{R}$ ) is between -1 to +1 . The closer the value of $\mathrm{R}$ is to 1 , the relationship between the independent variable and the dependent variable is stronger and negative, and vice versa. The correlation coefficient test itself aims as a measure of how far the ability of the dependent variable variation model is. The coefficient of determination $\left(\mathrm{R}^{2}\right)$ in the range of 0 to 1 , which means if approaching 0 then the model's ability to explain the dependent variable are very limited. On the other hand, if the coefficient of determination of the variable is closer to 1 , the independent variable will make the dependent variable stronger.

\section{e) Classic assumption test}

\section{1) Normality test}

Normality test aims to test whether in the regression model, the confounding or residual variables have a normal distribution (Ghozali, 2016). The assumption of the regression model is when the residuals are distributed close to normal or normal. Normality test can use Kolmogorov-Sminov. If the significance value is less than 0.05 , it means that the residuals studied are not normally distributed. On the other hand, if the significance value is more than 0.05 , it means that the residuals are normally distributed.

\section{2) Multicollinearity}

The multicollinearity test aims to test whether the regression model found a correlation between independent/independent variables (Ghozali, 2016). In the regression model, if the Varience Inflation Factor (VIF) value is above 0.1 and the value is below 10, it means that there is no multicollinearity value in the variable (Ghanimata \& Kamal, 2012).

\section{3) Linearity Test}

This test is used to see whether the specifications of the model used are correct or not (Ghozali, 2016). This linearity test uses Deviation from Linearity, if the significance value is more than 0.05 , it means that the independent and dependent variables have a linear relationship.

\section{4) Heteroscedasticity Test}

Heteroscedasticity test in this study using the Glejser test. The purpose of this test is to test whether there is an inequality of variance from the residuals for all observations in the linear regression model (Ghozali, 2016). If the sig value is more than 0.05 , then there is no heteroscedasticity. If the sig value is less than 0.05 , it means that heteroscedasticity has occurred.

\section{5) Autocorrelation Test}

The purpose of the autocorrelation test is to find out whether there is a correlation between the nuisance error in period $t$ and the error in the previous period (Ghozali, 2016). This test uses Durbin-Watson statistics. If the DW value is greater than du and less than 4-du, then there is no autocorrelation.

\section{$4 \quad$ Result and Discussion}

\subsection{Description of Research Variable}

Based on the results of research conducted through the distribution of questionnaires to 42 respondents, it can be seen the tendency of the answers to each statement in the independent variables, namely product quality (X1), price (X2), promotion (X3) and the dependent variable, namely purchasing decisions (Y). The measurement of the 
answer choices uses a Likert scale with a scale of 1-5. This is done in order to see the tendency of respondents' answers on each variable.

a) Cultural Factors Independent Variable (X1)

The cultural factor variable (X1) has three statements. Respondents' answers in answering each statement in the product quality variable are as follows.

Table 4.1. Frequency Distribution of Respondents for Cultural Factor Variables (X1)

\begin{tabular}{|c|c|c|c|c|c|c|c|c|}
\hline \multirow{2}{*}{\multicolumn{2}{|c|}{ Statement }} & \multicolumn{5}{|c|}{ Answer Score } & \multirow{3}{*}{$\begin{array}{r}\text { Average } \\
2.87\end{array}$} & \multirow{3}{*}{$\begin{array}{r}\begin{array}{c}\text { Std. Devi } \\
\text { ation }\end{array} \\
1,187\end{array}$} \\
\hline & & STS(1) & TS $(2)$ & KS(3) & $\mathbf{S}(4)$ & SS(5) & & \\
\hline $\mathrm{X} 1.1$ & $\begin{array}{l}\text { I use the services of a Wedding } \\
\text { Organizer because the majority of } \\
\text { other people do it too. }\end{array}$ & 13 & 26 & 29 & 19 & 10 & & \\
\hline $\mathrm{X} 1.2$ & $\begin{array}{l}\text { I use the services of a Wedding } \\
\text { Organizer because of the ease of } \\
\text { obtaining these services in the area } \\
\text { where I live }\end{array}$ & 4 & 8 & 16 & 36 & 33 & 3.89 & 1.098 \\
\hline $\mathrm{X} 1.3$ & $\begin{array}{l}\text { I use the services of a Wedding } \\
\text { Organizer because my ethnic group } \\
\text { also uses this service. }\end{array}$ & 24 & 28 & 24 & 16 & 5 & 2.48 & 1.182 \\
\hline
\end{tabular}

Source: Processed SPSS data, 2019

b) Social Factor Independent Variable (X2)

The price variable (X2) has three statements.

Table 4.2. Frequency Distribution of Respondents for Social Factor Variables (X2)

\begin{tabular}{|l|l|r|r|r|r|r|r|r|}
\hline \multicolumn{2}{|c|}{ Statement } & \multicolumn{2}{c|}{ Answer Score } & \multicolumn{2}{c|}{$\begin{array}{c}\text { Average } \\
\text { Std. Devi } \\
\text { ation }\end{array}$} \\
\cline { 2 - 7 } X2.1 & $\begin{array}{l}\text { I use the services of this Wedding } \\
\text { Organizer because of the influence } \\
\text { of friends. }\end{array}$ & 17 & 26 & 27 & 21 & 6 & 2.72 & 1,170 \\
\hline X2.2 & $\begin{array}{l}\text { I use the services of this Wedding } \\
\text { Organizer because of the family's } \\
\text { influence. }\end{array}$ & 11 & 25 & 28 & 23 & 10 & 2.96 & 1.172 \\
\hline X2.3 & $\begin{array}{l}\text { I use the services of this Wedding } \\
\text { Organizer because of the role and } \\
\text { status of my parents in society. }\end{array}$ & 14 & 27 & 26 & 18 & 12 & 2.87 & 1,239 \\
\hline
\end{tabular}

Based on these results, from the three statements above, we can see that customers feel that the influence of friends, family, and the role and status of parents in society is not a reason for them to use wedding organizer services.

c) Personal Factor Independent Variable (X3)

The personal factor variable (X3) has four statements.

Table 4.3. Frequency Distribution of Respondents for Personal Factor Variables (X3)

\begin{tabular}{|l|l|r|r|r|r|r|r|r|}
\hline \multicolumn{2}{|c}{ Statement } & \multicolumn{9}{|c|}{ Answer Score } & \multicolumn{2}{c|}{$\begin{array}{c}\text { Average } \\
\text { Std. Devi } \\
\text { ation }\end{array}$} \\
\cline { 2 - 7 } X3.1 & $\begin{array}{l}\text { I use the services of a Wedding } \\
\text { Organizer because of my busy work. }\end{array}$ & 0 & 1 & 3 & 42 & 51 & 4.47 & 0.614 \\
\hline X3.2 & $\begin{array}{l}\text { I use the services of this Wedding } \\
\text { Organizer because I can afford it. }\end{array}$ & 0 & 0 & 9 & 53 & 35 & 4.27 & 0.621 \\
\hline X3.3 & $\begin{array}{l}\text { I use the services of a Wedding } \\
\text { Organizer, this is part of my lifestyle }\end{array}$ & 24 & 35 & 36 & 1 & 1 & 2.18 & 0.854 \\
\hline X3.4 & $\begin{array}{l}\text { I use the services of the Wedding } \\
\text { Organizer that I have chosen because } \\
\text { the characteristics match what I want. }\end{array}$ & 0 & 2 & 4 & 65 & 26 & 4.19 & 0.601 \\
\hline
\end{tabular}

Source: Processed SPSS data, 2019

Based on these results, we can conclude that customers do not consider the use of wedding organizer services not as a lifestyle, but as their need for the presence of a third party who helps prepare for the event.

d) Purchase Decision Bound Variable (Y)

The purchasing decision variable $(\mathrm{Y})$ has four statements. 
Table 4.4. Frequency Distribution of Respondents for Purchase Decision Variables (Y)

\begin{tabular}{|c|c|c|c|c|c|c|c|c|}
\hline \multirow{2}{*}{\multicolumn{2}{|c|}{ Statement }} & \multicolumn{5}{|c|}{ Answer Score } & \multirow[t]{2}{*}{ Average } & \multirow{2}{*}{$\begin{array}{l}\text { Std. Devi } \\
\text { ation }\end{array}$} \\
\hline & & STS(1) & TS $(2)$ & KS(3) & $\mathbf{S ( 4 )}$ & SS(5) & & \\
\hline Y1 & $\begin{array}{l}\text { I use Wedding Organizer because of } \\
\text { my need for these services. }\end{array}$ & 2 & 1 & 15 & 38 & 41 & 4.19 & 0.882 \\
\hline $\mathrm{Y} 2$ & $\begin{array}{l}\text { I use Wedding Organizer because of } \\
\text { the availability of information about } \\
\text { these services. }\end{array}$ & 0 & 2 & 4 & 28 & 63 & 3.98 & 0.803 \\
\hline Y3 & $\begin{array}{l}\text { I use this Wedding Organizer that I } \\
\text { have chosen because I have compared } \\
\text { it with others }\end{array}$ & 1 & 1 & 8 & 20 & 67 & 4.09 & 0.914 \\
\hline Y4 & $\begin{array}{l}\text { I use the services of the Wedding } \\
\text { Organizer that I have chosen and I will } \\
\text { recommend it to other parties. }\end{array}$ & 0 & 2 & 11 & 17 & 67 & 4.04 & 0.934 \\
\hline
\end{tabular}

Source: Processed SPSS data, 2019

\subsection{Validity and Reliability Test}

\subsubsection{Validity test}

The processing results of the validity test can be seen in the following table:

Table 4.5 Validity Test Results

\begin{tabular}{|l|l|l|l|l|}
\hline Variable & Items & Correlation coefficient & Sig & Description \\
\hline X1 & X1.1 & 0,872 & 0,000 & Valid \\
\cline { 2 - 5 } & X1.2 & 0,748 & 0,000 & Valid \\
\cline { 2 - 5 } & X1.3 & 0,840 & 0,000 & Valid \\
\hline X2 & X2.1 & 0,674 & 0,000 & Valid \\
\cline { 2 - 5 } & X2.2 & 0,809 & 0,000 & Valid \\
\cline { 2 - 5 } & X2.3 & 0,790 & 0,000 & Valid \\
\hline X3 & X3.1 & 0,601 & 0,000 & Valid \\
\cline { 2 - 5 } & X3.2 & 0,540 & 0,000 & Valid \\
\cline { 2 - 5 } & X3.3 & 0,623 & 0,000 & Valid \\
\cline { 2 - 5 } & X3.4 & 0,489 & 0,000 & Valid \\
\hline \multirow{5}{*}{$Y$} & Y1 & 0,703 & 0,000 & Valid \\
\cline { 2 - 5 } & Y2 & 0,696 & 0,000 & Valid \\
\cline { 2 - 5 } & Y3 & 0,695 & 0,000 & Valid \\
\cline { 2 - 5 } & Y4 & 0,783 & 0,000 & Valid \\
\hline \multicolumn{2}{|c|}{ Source: Processed SPSS data, 2019 } \\
\hline
\end{tabular}

Table 4.5 shows that all statements on the independent variable quality of cultural factors (X1), social factors (X2), and personal factors (X3) and the dependent variable on purchasing decisions (Y) show a sig value. 0.000 where the value is 0.05 . Therefore, it can be concluded that each questionnaire statement in this study is said to be valid.

\subsubsection{Reliability Test}

Reliability testing using the Cronbach Alpha $(\alpha)$ method with a value of 0.6 (Sugiyono, 2014). The processing results from the reliability test can be seen in Table 4.2.2 below:

Table 4.6. Reliability Test Results

\begin{tabular}{|l|l|l|}
\hline Variable & Cronbach's Alpha & Description \\
\hline X1 & 0.835 & Reliable \\
\hline X2 & 0.807 & Reliable \\
\hline X3 & 0.690 & Reliable \\
\hline Y & 0.787 & Reliable \\
\hline \multicolumn{2}{|c|}{ Source: Processed SPSS data, 2019 }
\end{tabular}

Table 4.6 shows that the value of each variable in this study has a Cronbach Alpha 0.6, so it can be said that all variables in this study are reliable. 


\subsection{Data analysis method}

\subsubsection{Multiple Regression Analysis}

The following are the results of multiple regression analysis in this study:

Table 4.7. Results of Multiple Regression Analysis

\begin{tabular}{|c|c|c|c|c|c|}
\hline \multicolumn{6}{|l|}{ Coefficients $^{\mathrm{a}}$} \\
\hline \multirow{2}{*}{ Model } & \multicolumn{2}{|c|}{ Unstandardized Coefficients } & \multirow{2}{*}{$\begin{array}{l}\text { Standardized Coefficients } \\
\text { Beta }\end{array}$} & \multirow{2}{*}{$\mathrm{t}$} & \multirow{2}{*}{ Sig. } \\
\hline & B & Std. Error & & & \\
\hline (Constant) & 2.883 & .537 & & 5.374 & .000 \\
\hline X1_rata & .192 & .064 & .324 & 2.974 & .004 \\
\hline X2_rata & .014 & .064 & .023 & .211 & .834 \\
\hline X3_rata & .161 & .143 & .111 & 1.121 & .265 \\
\hline \multicolumn{6}{|c|}{ a. Dependent Variable: Y_rata } \\
\hline \multicolumn{6}{|c|}{ Source: Processed SPSS data, 2019} \\
\hline
\end{tabular}

Based on Table 4.7, it can be seen that the regression equation used in this study is:

$$
\mathrm{Y}=2.883+0.192 \mathrm{X}_{1}+0.014 \mathrm{X}_{2}+0.161 \mathrm{X}_{3}
$$

Description:

$$
\begin{array}{ll}
\mathrm{Y} & =\text { Purchase Decision } \\
\mathrm{X} 1 & =\text { Cultural Factor } \\
\mathrm{X} 2 & =\text { Social Factor } \\
\mathrm{X} 3 & =\text { Personal Factor }
\end{array}
$$

The interpretation of the above equation based on the analysis of the regression coefficient values is:

1. The coefficient value of $\mathrm{X} 1$ (cultural factor) is positive at 0.192 , meaning that the $\mathrm{X} 1$ variable (cultural factor) has a positive relationship to $\mathrm{Y}$ (purchase decision). If the cultural factor increases by one unit, the purchasing decision increases by 0.192 units.

2. The value of the $\mathrm{X} 2$ coefficient (social factor) is positive at 0.014 , meaning that the $\mathrm{X} 2$ variable (social factor) has a positive relationship to $\mathrm{Y}$ (purchase decision). If the social factor increases by one unit, the purchasing decision increases by 0.014 units.

3. The coefficient value of $\mathrm{X} 3$ (personal factor) is positive at 0.161 , meaning that the variable $\mathrm{X} 3$ (personal factor) has a positive relationship to $\mathrm{Y}$ (purchase decision). If the personal factor increases by one unit, the

\begin{tabular}{|c|c|c|c|c|c|c|}
\hline \multicolumn{7}{|c|}{ ANOVA $^{a}$} \\
\hline & & Sum of Squares & df & Mean Square & $\mathrm{F}$ & Sig. \\
\hline \multirow{3}{*}{1} & Regression & 4.138 & 3 & 1.379 & 5.030 & $.003^{b}$ \\
\hline & Residual & 25.503 & 93 & .274 & & \\
\hline & Total & 29.640 & 96 & & & \\
\hline \multicolumn{7}{|c|}{ a. Dependent Variable: Y_rata } \\
\hline \multicolumn{7}{|c|}{ b. Predictors: (Constant), X3_rata, X2_rata, X1_rata } \\
\hline
\end{tabular}
purchase decision increases by 0.161 units.

\subsubsection{F Uji test}

The following are the results of the $\mathrm{F}$ test in this study:

Table 4.8. F Test Results

Based on Table 5.8, it can be seen that the $F$ test value is 5.030 with a significance of 0.003 (sig. 0.05). Therefore, it can be concluded that the independent variables, namely cultural factors, social factors and personal factors simultaneously have a significant influence on the dependent variable, namely purchasing decisions. 


\subsection{3. $\quad$ t test}

The following are the results of the t-test in this study:

Tabel 4.9. Hasil Uji t

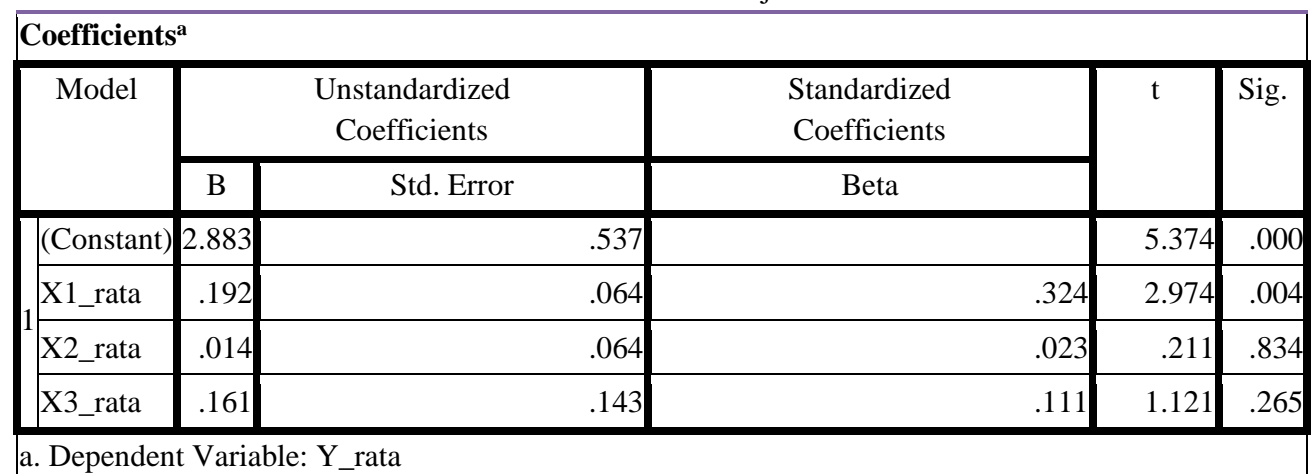

Source: Processed SPSS Data, 2019

Based on table 5.9 shows that the value of sig. on the X1 variable (cultural factor) is 0.004 (sig. 0.05 ), so it is concluded that the X1 variable (cultural factor) has a significant effect on the $\mathrm{Y}$ variable (purchase decision) partially. However, the p-value of the variables X2 (social factors) and X3 (personal factors) shows the number > 0.05 , so that these variables do not have a significant effect on variable Y (purchase decisions) partially.

\subsubsection{Correlation Coefficient And Coefficient Of Determination}

The following are the results of the coefficient of determination in this study:

Table 4.10. Coefficient of Determination Test Results

\begin{tabular}{|r|c|r|r|r|}
\hline \multicolumn{1}{|l|}{ Model Summary } \\
\hline Model & R & R Square & Adjusted R Square & Std. Error of the Estimate \\
\hline 1 & .374 & .140 & .112 & .524 \\
\hline \multicolumn{5}{|c|}{ a. Predictors: (Constant), X3_rata, X2_rata, X1_rata } \\
\hline \multicolumn{5}{|c|}{ Source: Processed SPSS Data, 2019 }
\end{tabular}

Based on Table 4.10. the magnitude of $\mathrm{R}$ is 0.374 and the amount of $\mathrm{R}^{2}$ was 0.140 or $14 \%$. So it can be concluded from the results of the correlation coefficient and the coefficient of determination from the results of these calculations, that the relationship between the independent variable and the dependent variable is strong. While the dependent variable (purchase decisions) can be explained by the independent variables (cultural factors, social factors, and personal factors) of only $14 \%$, which means the ability to explain it is very limited because as much as $84 \%$ is explained by other independent variables not examined in this study.

\subsection{Classic assumption test}

\subsubsection{Normality test}

The following are the results of the normality test in this study:

Table 4.11. Normality Test Results

\begin{tabular}{|c|c|c|}
\hline \multicolumn{3}{|c|}{ One-Sample Kolmogorov-Smirnov Test } \\
\hline & & $\begin{array}{c}\text { Unstandardized } \\
\text { Residual }\end{array}$ \\
\hline \multicolumn{2}{|l|}{$\mathrm{N}$} & 97 \\
\hline \multirow{2}{*}{ Normal Parameters ${ }^{\mathrm{a}, \mathrm{b}}$} & Mean & $0 \mathrm{E}-7$ \\
\hline & Std. Deviation & .51541514 \\
\hline \multirow{3}{*}{ Most Extreme Differences } & Absolute & .045 \\
\hline & Positive & .042 \\
\hline & Negative & -.045 \\
\hline \multicolumn{2}{|l|}{ Kolmogorov-Smirnov Z } & .446 \\
\hline \multicolumn{2}{|l|}{ Asymp. Sig. (2-tailed) } & .989 \\
\hline \multicolumn{3}{|c|}{ a. Test distribution is Normal. } \\
\hline \multicolumn{3}{|l|}{ b. Calculated from data. } \\
\hline
\end{tabular}


Based on Table 5.11 above, it can be seen that the Kolmogorov Smirnov test produces a significance value of 0.989 . This value is greater than 0.05 , so it can be concluded that the residuals are normally distributed.

\subsubsection{Multicollinearity Test}

The following are the results of the multicollinearity test in this study:

Table 4.12. Multicollinearity Test Results

\begin{tabular}{|c|c|c|c|c|c|c|c|}
\hline \multicolumn{8}{|l|}{ Coefficients $^{\mathrm{a}}$} \\
\hline \multirow[t]{2}{*}{ Model } & \multicolumn{2}{|c|}{$\begin{array}{c}\text { Unstandardized } \\
\text { Coefficients }\end{array}$} & \multirow{2}{*}{$\begin{array}{c}\begin{array}{c}\text { Standardized } \\
\text { Coefficients }\end{array} \\
\text { Beta }\end{array}$} & \multirow[t]{2}{*}{$\mathrm{t}$} & \multirow[t]{2}{*}{ Sig. } & \multicolumn{2}{|c|}{$\begin{array}{l}\text { Collinearity } \\
\text { Statistics }\end{array}$} \\
\hline & B & Std. Error & & & & Tolerance & VIF \\
\hline (Constant) & 2.883 & .537 & & 5.374 & .000 & & \\
\hline X1_rata & .192 & .064 & .324 & 2.974 & .004 & .782 & 1.280 \\
\hline X2_rata & .014 & .064 & .023 & .211 & .834 & .787 & 1.271 \\
\hline X3_rata & .161 & .143 & .111 & 1.121 & .265 & .948 & 1.055 \\
\hline
\end{tabular}

\section{Source: Processed SPSS Data, 2019}

Based on Table 4.12, it can be seen that the tolerance value is $>0.1$ and the variance inflation factor (VIF) 10 , so it can be concluded that in the regression model there is no multicollinearity or no correlation between independent variables.

\subsubsection{Linearity Test}

The following are the results of the linearity test in this study:

Table 4.13. Linearity Test Results X1 with $Y$

\begin{tabular}{|c|c|c|c|c|c|c|c|}
\hline \multicolumn{8}{|c|}{ ANOVA Table } \\
\hline & & & $\begin{array}{c}\text { Sum of } \\
\text { Squares }\end{array}$ & df & $\begin{array}{l}\text { Mean } \\
\text { Square }\end{array}$ & $\mathrm{F}$ & Sig. \\
\hline \multirow{5}{*}{$\begin{array}{l}\text { Y_rata * } \\
\mathrm{X} 1 \text { _rata }\end{array}$} & \multirow{3}{*}{$\begin{array}{l}\text { Between } \\
\text { Groups }\end{array}$} & (Combined) & 6.544 & 11 & .595 & 2.189 & .022 \\
\hline & & Linearity & 3.763 & 1 & 3.763 & 13.847 & .000 \\
\hline & & Deviation from Linearity & 2.781 & 10 & .278 & 1.023 & .431 \\
\hline & \multicolumn{2}{|c|}{ Within Groups } & 23.097 & 85 & .272 & & \\
\hline & \multicolumn{2}{|l|}{ Total } & 29.640 & 96 & & & \\
\hline
\end{tabular}

Source: Processed SPSS data, 2019

Based on Table 4.13 showing the results of a linearity significance of 0.4310 .05 , it can be concluded that there is a linear relationship between cultural factors (X1) and purchasing decisions (Y).

Table 4.14. X2 Linearity Test Results with Y

\begin{tabular}{|c|c|c|c|c|c|c|c|}
\hline \multicolumn{8}{|c|}{ ANOVA Table } \\
\hline & & & $\begin{array}{l}\text { Sum of } \\
\text { Squares }\end{array}$ & $\mathrm{df}$ & $\begin{array}{l}\text { Mean } \\
\text { Square }\end{array}$ & $\mathrm{F}$ & Sig. \\
\hline \multirow{5}{*}{$\begin{array}{l}\text { Y_rata * } \\
\text { X2_rata }\end{array}$} & \multirow{3}{*}{$\begin{array}{l}\text { Between } \\
\text { Groups }\end{array}$} & (Combined) & 5.819 & 12 & .485 & 1.710 & .079 \\
\hline & & Linearity & 1.063 & 1 & 1.063 & 3.750 & .056 \\
\hline & & Deviation from Linearity & 4.756 & 11 & .432 & 1.525 & .138 \\
\hline & \multicolumn{2}{|c|}{ Within Groups } & 23.821 & 84 & .284 & & \\
\hline & \multicolumn{2}{|l|}{ Total } & 29.640 & 96 & & & \\
\hline
\end{tabular}

Source: Processed SPSS data, 2019

Based on Table 4.14 showing the results of a linearity significance of 0.0560 .05 , it can be concluded that there is a linear relationship between social factors (X2) and purchasing decisions (Y). 
Table 4.15. X3 Linearity Test Results with Y

\begin{tabular}{|c|c|c|c|c|c|c|c|}
\hline \multicolumn{8}{|c|}{ ANOVA Table } \\
\hline & & & $\begin{array}{l}\text { Sum of } \\
\text { Squares }\end{array}$ & df & $\begin{array}{l}\text { Mean } \\
\text { Square }\end{array}$ & $\mathrm{F}$ & Sig. \\
\hline \multirow{5}{*}{$\begin{array}{l}\text { Y_rata * } \\
\text { X3_rata }\end{array}$} & \multirow{3}{*}{$\begin{array}{l}\text { Between } \\
\text { Groups }\end{array}$} & (Combined) & 2.462 & 7 & .352 & 1.152 & .339 \\
\hline & & Linearity & .965 & 1 & .965 & 3.161 & .079 \\
\hline & & Deviation from Linearity & 1.497 & 6 & .250 & .817 & .560 \\
\hline & \multicolumn{2}{|c|}{ Within Groups } & 27.178 & 89 & .305 & & \\
\hline & \multicolumn{2}{|l|}{ Total } & 29.640 & 96 & & & \\
\hline
\end{tabular}

Source: Processed SPSS data, 2019

Based on Table 4.16 shows the results of a linearity significance of 0.5600 .05 , it can be concluded that there is a linear relationship between personal factors (X3) and purchasing decisions (Y).

\subsubsection{Heteroscedasticity Test}

The following are the results of the heteroscedasticity test in this study:

Table 4.17. Heteroscedasticity Test Results

\begin{tabular}{|c|c|c|c|c|c|}
\hline \multicolumn{6}{|l|}{ Coefficients $^{\mathrm{a}}$} \\
\hline \multirow[t]{2}{*}{ Model } & \multicolumn{2}{|c|}{$\begin{array}{l}\text { Unstandardized } \\
\text { Coefficients }\end{array}$} & $\begin{array}{l}\text { Standardized } \\
\text { Coefficients }\end{array}$ & $\mathrm{t}$ & Sig. \\
\hline & B & Std. Error & Beta & & \\
\hline (Constant) & .327 & .322 & & 1.016 & .312 \\
\hline X1_rata & -.021 & .039 & -.062 & -.534 & .594 \\
\hline X2_rata & -.019 & .039 & -.056 & -.485 & .629 \\
\hline X3_rata & .053 & .086 & .065 & .615 & .540 \\
\hline
\end{tabular}

Source: Processed SPSS data, 2019

Based on Table 4.17 it can be seen that the probability value of the cultural factor variable $(\mathrm{X} 1)=0.594$, the probability value of the social factor variable $(X 2)=0.629$, and the probability value of the personal factor variable $(\mathrm{X} 3)=0.540$. Because the probability value of all variables is more than 0.05 , it can be concluded that all variables do not occur heteroscedasticity.

\subsubsection{Autocorrelation Test}

The following are the results of the autocorrelation test in this study:

\begin{tabular}{|c|c|c|c|c|c|c|c|c|c|c|}
\hline \multicolumn{11}{|c|}{ Table 4.18. Autocorrelation Test Results } \\
\hline \multirow[t]{2}{*}{ Model } & \multirow[t]{2}{*}{$\mathrm{R}$} & \multirow[t]{2}{*}{ R Square } & \multirow{2}{*}{$\begin{array}{l}\text { Adjusted R } \\
\text { Square }\end{array}$} & \multirow{2}{*}{$\begin{array}{l}\text { Std. Error of the } \\
\text { Estimate }\end{array}$} & \multicolumn{5}{|c|}{ Change Statistics } & \multirow{2}{*}{$\begin{array}{l}\text { Durbin- } \\
\text { Watson }\end{array}$} \\
\hline & & & & & $\begin{array}{l}\text { R Square } \\
\text { Change }\end{array}$ & F Change & df1 & df 2 & $\begin{array}{l}\text { Sig. F } \\
\text { Change }\end{array}$ & \\
\hline 1 & $.107^{\mathrm{a}}$ & .011 & -.020 & .31445 & .011 & .360 & 3 & 93 & .782 & 1.983 \\
\hline
\end{tabular}

a. Predictors: (Constant), X3_rata, X2_rata, X1_rata

b. Dependent Variable: ABS_RES

\section{Source: Processed SPSS data, 2019}

Based on Table 4.4.5, it can be seen that the Durbin-Watson value is 1.983. It is known from the regression model above that there are 3 independent variables and 1 dependent variable with a total sample of 97 respondents. Then the value of $\mathrm{T}=97, \mathrm{~K}=3$. Furthermore, the Durbin-Watson table looks for the DL and DU values at $\mathrm{T}=97, \mathrm{~K}=3$, where the $\mathrm{DU}$ value is 1.7335 and the value (4-DU) is 2.2665 .

Based on these results, it can be concluded that there is no autocorrelation, because the Durbin-Watson value is between DU and (4-DU). 


\section{Conclusions and Practical Implication}

Based on the results of statistical data analysis, using a sample of 97 respondents and data collection methods through questionnaires, it can be concluded that:

1. Cultural factors have a significant effect on purchasing decisions. This shows that the first hypothesis (H1) can be accepted.

2. Social factors have no significant effect on purchasing decisions so that the second hypothesis $(\mathrm{H} 2)$ is rejected.

3. Personal factors have no significant effect on purchasing decisions so that the second hypothesis (H3) is rejected.

\subsection{Managerial Implications}

Table 5.1. Managerial Implications

\begin{tabular}{|c|c|c|}
\hline Variable & Before Research & After Research \\
\hline $\begin{array}{l}\text { Cultural } \\
\text { Factors (X1) }\end{array}$ & $\begin{array}{l}\text { - Marketing to people around the area where they } \\
\text { live, and to people who need this service. } \\
\text { - Haven't considered strengthening ethnicity and } \\
\text { culture at the wedding. }\end{array}$ & $\begin{array}{l}\text { Maintain marketing to people around Bolodewe area. } \\
\text { Marketing more to the same tribe and trying to learn the } \\
\text { wedding customs of other tribes in order to develop the } \\
\text { company. }\end{array}$ \\
\hline $\begin{array}{l}\text { Social Factors } \\
\text { (X2) }\end{array}$ & - Focus on marketing only to friends and family. & $\begin{array}{l}\text { - Continue to market through friends and family but can also } \\
\text { target other reference groups. } \\
\text { - Marketing in religious organizations, trade associations or } \\
\text { businesses. }\end{array}$ \\
\hline $\begin{array}{l}\text { Personal } \\
\text { Factor (X3) }\end{array}$ & $\begin{array}{l}\text { - View that the use of wedding } \\
\text { organizer services is part of a lifestyle. } \\
\text { - Low price is the essence to gain market. } \\
\text { - Not paying attention to the client's life stage. }\end{array}$ & $\begin{array}{l}\text { - Bolodewe considers delving into the client's side of life. } \\
\text { - Strive more to earn the trust of clients. } \\
\text { - Considering price increases by looking at the economic } \\
\text { situation by providing more value than just services. }\end{array}$ \\
\hline
\end{tabular}

Source: Data processed by the author

\section{References}

Ghanimata, F., \& Kamal, M. (2012). Analisis pengaruh harga, kualitas produk, dan lokasi terhadap keputusan pembelian (Studi pada pembeli produk Bandeng Juwana Elrina Semarang). Fakultas Ekonomika dan Bisnis.

Ghozali, I. (2016). Aplikasi analisis multivariete dengan program IBM SPSS 23 (8th ed.). Semarang: Badan Penerbit Universitas Diponegoro.

Kotler, P., \& Amstrong, G. (2016). Principles of marketing (16th ed.). New Jersey: Pearson Prentince Hall.

Kotler, P., \& Keller, K. L. (2012). Manajemen pemasaran. Jilid 1 (12nd ed.). Jakarta: Erlangga.

Kotler, P., \& Keller, K. L. (2016a). Marketing management (5th ed.). New Jersey : Pearson Education South Asia PTe Ltd.

Kotler, P., \& Keller, K. L. (2016b). Marketing management (Edisi ke-1). Pearson Education Limited 2016.

Napompech, K. (2014). Attributes influencing wedding studio choice. Journal of Applied Sciences, 14(21), 2685-2694. https://doi.org/10.3923/jas.2014.2685.2694

Nawawi, M. T. (2016). Factors of consumer behavior that affect purchasing decisions on Blackberry Smartphone. The Winners, 17(1), 59-66. https://doi.org/10.21512/tw.v17i1.1810

Nofri, O., \& Hafifah, A. (2018). Analisis perilaku konsumen dalam melakukan online shopping di Kota Makassar. Jurnal Minds: Manajemen Ide Dan Inspirasi, 5(1), 113-132. https://doi.org/10.24252/minds.v5i1.5054

Pemani, P. O. S., Massie, J. D. D., \& Tielung, M. V. J. (2017). The effect of personal factors on consumer purchase decision (Case study: Everbest Shoes). Jurnal EMBA: Jurnal Riset Ekonomi, Manajemen, Bisnis Dan Akuntansi, 5(1), 68-77. https://doi.org/10.35794/emba.5.1.2017.15451

Rambi, W. (2015). Pengaruh perilaku lonsumen dalam keputusan pembelian dari Xiaomi Cellphone di Manado. Jurnal EMBA: Jurnal Riset Ekonomi, Manajemen, Bisnis Dan Akuntansi, 3(2), 917-927.

https://doi.org/10.35794/emba.3.2.2015.9247 
Sarwono, J. (2006). Metode penelitian kuantitatif dan kualitatif (1st ed.). Yogyakarta: Graha Ilmu.

Schiffman, L. ., \& Kanuk, L. L. (2010). Consumer behavior (10th ed.). New Jersey : Pearson Prentice Hall.

Sopiah, \& Sangadji, E. M. (2013). Perilaku konsumen pendekatan praktis disertai himpunan jurnal penelitian. CV. Andi Offset.

Suawa, A. J., Tumbel, A. L., \& Mandagie, Y. (2019). Analisis faktor faktor yang mempengaruhi perilaku konsumen terhadap keputusan pembelian di New Ayam Bandung Resto kawasan Megamas Manado. Jurnal EMBA: Jurnal Riset Ekonomi, Manajemen, Bisnis Dan Akuntansi, 7(4), 5195-5204. https://doi.org/10.35794/emba.v7i4.26128

Sugiyono. (2014). Metode penelitian bisnis (18th ed.). Jakarta: Alfabeta.

Sumarwan, U. (2015). Perilaku konsumen (Cetakan ketiga) (Kedua). Jakarta : Ghalia Indonesia. 